\title{
COPYING
}

No contents may be reproduced by any means without the permission of Cambridge University Press. This journal is registered with the Copyright Clearance Center, 222 Rosewood Drive, Danvers, MA 01923, USA (www.copyright.com). Organizations in the USA who are also registered with the CCC may therefore copy material (beyond the limits permitted by sections 107 and 108 of US copyright law) subject to payment to CCC. This consent does not extend to multiple copying for promotional or commercial purposes. ISI Tear Sheet Service, 3501 Market Street, Philadelphia, PA 19106, USA, is authorized to supply single copies of separate articles for private use only. Organizations authorized by the Copyright Licensing Agency may also copy material subject to the usual conditions. For all other use, permission should be sought from Cambridge or the American Branch of Cambridge University Press.

\section{INTERNET ACCESS}

This journal is included in the Cambridge Journals Online service which can be found at http://www.journals.cambridge.org For further information on other Press titles access www.cambridge.org

This journal issue has been printed on FSC-certified paper and cover board. FSC is an independent, non-governmental, not-for-profit organization established to promote the responsible management of the world's forests. Please see www.fsc.org for information.

\section{CAMBRIDGE UNIVERSITY PRESS}

The Edinburgh Building, Shaftesbury Road, Cambridge CB2 8RU, United Kingdom

32 Avenue of the Americas, New York, NY 10013-2473, USA

477 Williamstown Road, Port Melbourne, VIC 3207, Australia

Ruiz de Alarcón 13, 28014 Madrid, Spain

Dock House, The Waterfront, Cape Town 8001, South Africa

Printed in the United Kingdom by the University Press, Cambridge 


\section{THE JOURNAL OF}

\section{AGRICULTURAL SCIENCE}

\section{CONTENTS}

\section{CLIMATE CHANGE AND AGRICULTURE PAPERS}

M. A. Igbal, J. Eitzinger, H. Formayer, A. Hassan and L. K. Heng A simulation study for assessing yield optimization and potential for water reduction for summer-sown maize under different climate change scenarios

V. VUČETIĆ Modelling of maize production in Croatia: present and future climate

P. Liu, W. Guo, Z. Jiang, H. Pu, C. Feng, X. Zhu, Y. Peng, A. Kuang and C. R. Little Effects of high temperature after anthesis on starch granules in grains of wheat (Triticum aestivum L.)

A. UtSET and B. Del Río Reliability of current Spanish irrigation designs in a changed climate: a case study

E. KocmÁnKová, M. TrnKa, J. Eitzinger, M. DubrovskÝ, P. ŠTĚPÁNeK, D. SEMERÁdovÁ, J. BALEK, P. SKALAK, A. FARDA, J. JUROCH and Z. ŽAlud Estimating the impact of climate change on the occurrence of selected pests at a high spatial resolution: a novel approach

\section{CROPS AND SOILS PAPERS}

I. S. TokAtLidis, C. Tsikrikoni, A. S. Lithourgidis, J. T. Tsialtas and C. Tzantarmas Intra-cultivar variation in cotton: response to single-plant yield selection at low density

K. ZHANG, Y. Li and L. LIAN Pollen-mediated transgene flow in maize grown in the Huang-huai-hai region in China

R. Kumar, G. S. Kang, S. K. PAndeY and J. Gopal Genetic base and relatedness of Indian early maturing potato (Solanum tuberosum) selections

\section{ANIMAL PAPERS}

M. AlAMER Water requirements and body water distribution in Awassi sheep and Aardi goats during winter and summer seasons

J. G. Evans, M. D. Fraser, I. Owen and D. A. Davies An evaluation of two perennial ryegrass cultivars (AberDart and Fennema) for sheep production in the uplands

A. Faridi, M. Mottaghitalab, H. Darmani-Kuhi, J. France and H. Ahmadi Predicting carcass energy content and composition in broilers using the group method of data handling-type neural networks

FORTHCOMING EVENTS 